Sains Malaysiana 50(9)(2021): 2615-2624

http://doi.org/10.17576/jsm-2021-5009-10

\title{
Influence of Bacterial Inoculation on Growth and Plant Nutrition of Peach Grafted in Different Rootstocks in Calcareous Soil
}

(Kesan Inokulasi Bakteria ke atas Pertumbuhan dan Nutrisi Tumbuhan Tanaman Pic yang Dicantum pada Stok Akar Berbeza di Tanah Berkapur)

\author{
MuZaffer İpeK*, Şeyma Arikan, Ahmet Eşitken, LÜtfi Pirlak, Mesude Figen Dönmez \& Metin Turan
}

\section{ABSTRACT}

The highly calcareous soil limits plant growth parameters due to inadequate uptake of plant nutrients. Calcareous soil conditions affect plant growth through impaired chlorophyll synthesis, root growth, enzyme synthesis, and nutrient uptake. To overcome the negative effect of calcareous soil, six bacterial strains namely Alcaligenes 637Ca, Agrobacterium A18, Staphylococcus MFDCa1, Staphylococcus MFDCa2, Bacillus M3, and Pantoea FF1 were inoculated in one-yearold plants of peach cultivar 'Elegant Lady' grafted onto GF677 and Nemaguard rootstocks. The bacterial treatments were observed to improve plant growth and nutrient content compared to the control. Moreover, the GF677 rootstock was observed to be more tolerant to high calcareous soil conditions than Nemaguard, showing better plant growth and nutrient content. At the Nemaguard rootstocks, the largest leaf area was observed to be upon inoculation with MFDCa2 $\left(29.1 \mathrm{~cm}^{2}\right), F F 1\left(28.8 \mathrm{~cm}^{2}\right)$, and M3 $\left(28.1 \mathrm{~cm}^{2}\right)$, whereas at the GF677 rootstock, the highest leaf area was observed upon inoculation with MFDCal $\left(34.7 \mathrm{~cm}^{2}\right), F F 1\left(32.6 \mathrm{~cm}^{2}\right)$, and $637 \mathrm{Ca}\left(31.5 \mathrm{~cm}^{2}\right)$. The leaf iron content was higher in bacterial treatments than the control. In the Nemaguard rootstock, the highest iron content was measured in plants inoculated with $637 \mathrm{Ca}\left(133.49 \mathrm{mg} \mathrm{kg}^{-1}\right)$ and $\mathrm{M3}\left(127.64 \mathrm{mg} \mathrm{kg}^{-1}\right)$, whereas in the GF677 rootstock, the treatments MFDCal (131.51 mg kg-1), 637Ca (131.21 $\left.\mathrm{mg} \mathrm{kg}^{-1}\right), \mathrm{FF1}\left(127.72 \mathrm{mg} \mathrm{kg}^{-1}\right)$, and M3 (127.68 $\left.\mathrm{mg} \mathrm{kg}^{-1}\right)$ resulted in high iron content. The results indicate that bacterial inoculations have a significant potential to improve plant growth and can be used as biofertilizers for peach grafted onto Nemaguard and GF677 in high calcareous soil conditions.

Keywords: Calcareous soil; peach; plant growth-promoting rhizobacteria (PGPR); plant nutrition; Prunus persica L.

\section{ABSTRAK}

Tanah yang sangat berkapur mengehadkan pertumbuhan tanaman kerana pengambilan nutrien tumbuhan yang tidak mencukupi. Keadaan tanah berkapur mempengaruhi pertumbuhan tanaman dengan menjejaskan sintesis klorofil, pertumbuhan akar, sintesis enzim dan pengambilan nutrien. Untuk mengatasi kesan negatif tanah berkapur, enam strain bakteria iaitu Alcaligenes 637Ca, Agrobacterium A18, Staphylococcus MFDCa1, Staphylococcus MFDCa2, Bacillus M3 dan Pantoea FF1 telah diinokulasi pada tanaman pic kultivar 'Elegant Lady'yang berusia satu tahun yang dicantumkan kepada stok akar GF677 dan Nemaguard. Rawatan bakteria didapati telah meningkatkan pertumbuhan tanaman dan kandungan nutrien dibandingkan dengan kawalannya. Tambahan pula, stok akar GF677 dilihat lebih tolerans terhadap keadaan tanah berkapur berbanding Nemaguard, serta menunjukkan pertumbuhan tanaman dan kandungan nutrien yang lebih baik. Pada stok akar Nemaguard, keluasan daun diperhatikan pada inokulasi dengan MFDCa2 (29.1 cm $\left.\mathrm{cm}^{2}\right)$, FF1 $\left(28.8 \mathrm{~cm}^{2}\right)$ dan M3 $\left(28.1 \mathrm{~cm}^{2}\right)$, sedangkan pada stok akar GF677, keluasan daun terbesar diperhatikan pada inokulasi dengan MFDCal $\left(34.7 \mathrm{~cm}^{2}\right)$, FFl $\left(32.6 \mathrm{~cm}^{2}\right)$ dan $637 \mathrm{Ca}\left(31.5 \mathrm{~cm}^{2}\right)$. Kandungan zat besi dalam daun didapati lebih tinggi dalam rawatan bakteria berbanding kawalannya. Pada stok akar Nemaguard, kandungan zat besi tertinggi diukur pada tanaman yang diinokulasi dengan 637Ca (133.49 mg/kg) dan M3 (127.64 $\mathrm{mg} / \mathrm{kg}$ ), manakala pada stok akar GF677, rawatan MFDCa1 (131.51 mg/kg), 637Ca (131.21 mg/kg), FF1 (127.72 mg/kg) dan M3 (127.68 mg/kg) menghasilkan kandungan zat besi yang tinggi. Hasil menunjukkan bahawa inokulasi bakteria berpotensi besar untuk meningkatkan pertumbuhan tanaman dan dapat digunakan sebagai bio-baja untuk tanaman pic yang dicantumkan kepada stok akar Nemaguard dan GF677 dalam keadaan tanah berkapur.

Kata kunci: Nutrisi tumbuhan; Prunus persica L.; rhizobakteria penggalak pertumbuhan tanaman (PGPR); tanah berkapur; tanaman pic 


\section{INTRODUCTION}

More than $30 \%$ of the soil on the earth's surface is calcareous (Marschner 1995) and approximately $70 \%$ of the orchards in Turkey have been established in calcareous soil containing more than $30 \%$ total calcium carbonate $\left(\mathrm{CaCO}_{3}\right)$. The high $\mathrm{CaCO}_{3}$ content raises the soil $\mathrm{pH}$ to between 7.5 and 8.5. The high $\mathrm{pH}$ and bicarbonate $\left(\mathrm{HCO}_{3}\right)$ concentration cause a low bioavailability of micro- and macronutrients, especially iron (Fe) and phosphorus $(\mathrm{P})$. Although the $\mathrm{Fe}$ requirements of fruit trees are relatively low, the Fe content in soils is insufficient for uptake by some fruit species, which are grown on calcareous soils. The fruit species, including apples, pears, peaches, quinces, strawberries, and citrus species are most sensitive to $\mathrm{CaCO}_{3}$ and/or calcium bicarbonate $\left(\mathrm{Ca}\left(\mathrm{HCO}_{3}\right)_{2}\right)$ (Loeppert 1986). The insufficient $\mathrm{Fe}$ concentration in the soil leads to the lower synthesis of chlorophyll by the leaves, resulting in a lower rate of photosynthesis. This reduced photosynthetic activity in susceptible plant species limits the root growth, which resulted in a reduction in the plant biomass. Perennial fruit species that form smaller trees may have smaller fruits (Marschner 1995). Thus, lime-induced iron chlorosis limits the yield and profit for fruit growers.

To overcome this, growers of fruit trees use tolerant rootstocks or more $\mathrm{Fe}^{3+}$ chelated fertilizers. However, only a limited number of rootstocks tolerant to limeinduced iron chlorosis are available for fruit species, while chemical fertilization is expensive and possess environmental concerns (Sorrenti et al. 2012; Tagliavini \& Rombolà 2001). In the last decades, sustainable agricultural systems and bio fertilization have been proposed to be a solution in adverse environmental conditions (Eşitken et al. 2003, 2002; Karakurt \& Aslantas 2010). Several species of bacteria exert beneficial effects on plant growth and development (Arikan \& Pirlak 2016; Arikan et al. 2020), nutrient availability (Ipek et al. 2014; Karakurt \& Aslantas 2010), synthesis of phytohormones such as auxins, cytokines, and gibberellins (Arikan \& Pirlak 2016; Egamberdiyeva 2005; García de Salamone et al. 2001). These bacteria are called plant growth-promoting rhizobacteria (PGPR). Some PGPRs also show beneficial effects on Fe-deficiency (Zhang et al. 2009).

In this study, the effects of PGPR on the plant growth and leaf mineral content of the peach cultivar 'Elegant Lady' grafted on the rootstocks GF677 and Nemaguard were investigated under high calcareous soil conditions.

\section{MATERIALs AND METHODS}

The present study aimed to determine the effects of some PGPR strains (Alcaligenes 637Ca, Agrobacterium A18, Staphylococcus MFDCa1, Staphylococcus MFDCa2, Bacillus M3, and Pantoea FF1) on plant growth and plant nutrition of the peach cultivar 'Elegant Lady' grafted onto two different rootstocks, Nemaguard and GF677. One-year-old plants of the peach cultivar 'Elegant Lady' grafted onto Nemaguard and GF677 rootstocks were used as the plant material and were obtained from a local commercial nursery. The orchard was established at $38^{\circ} 01^{\prime} 55^{\prime \prime} \mathrm{N}$ latitude and $32^{\circ} 30^{\prime} 21^{\prime \prime} \mathrm{E}$ longitude, at an elevation of $1175 \mathrm{~m}$ above sea level. The soil properties of the orchard are presented in Table 1. Briefly, the orchard soil had high calcareous content of $25.66 \%$, low organic matter (2.22\%) and high soil pH (7.60).

TABLE 1. Soil properties of the orchard

\begin{tabular}{|c|c|c|c|c|c|}
\hline \multicolumn{2}{|c|}{ Soil texture } & \multicolumn{2}{|c|}{ Macro-nutrients } & \multicolumn{2}{|c|}{ Micro-nutrients } \\
\hline pH (\%) & 7.60 & Total N (\%) & 0.0011 & $\mathrm{Fe}(\mathrm{mg} / \mathrm{kg})$ & 3.33 \\
\hline Organic matter (\%) & 2.22 & $\mathrm{NH}_{4}-\mathrm{N}(\mathrm{mg} / \mathrm{kg})$ & 9.50 & $\mathrm{Cu}(\mathrm{mg} / \mathrm{kg})$ & 1.85 \\
\hline $\mathrm{CaCO}_{3}(\%)$ & 25.66 & $\mathrm{NO}_{3}-\mathrm{N}(\mathrm{mg} / \mathrm{kg})$ & 10.40 & $\mathrm{Mn}(\mathrm{mg} / \mathrm{kg})$ & 5.28 \\
\hline $\mathrm{CEC}\left(\mathrm{cmol} \mathrm{kg}^{-1}\right)$ & 33.19 & $\mathrm{P}(\mathrm{mg} / \mathrm{kg})$ & 12.10 & $\mathrm{Zn}(\mathrm{mg} / \mathrm{kg})$ & 1.24 \\
\hline Sand (\%) & 46.01 & $\mathrm{~K}(\mathrm{mg} / \mathrm{kg})$ & 2.71 & $\mathrm{~B}(\mathrm{mg} / \mathrm{kg})$ & 0.32 \\
\hline Clay (\%) & 24.69 & $\mathrm{Mg}(\mathrm{mg} / \mathrm{kg})$ & 2.89 & $\mathrm{Na}(\mathrm{mg} / \mathrm{kg})$ & 1.01 \\
\hline Silt (\%) & 29.30 & $\mathrm{Ca}(\mathrm{cmol} / \mathrm{kg})$ & 12.42 & & \\
\hline $\mathrm{EC}(\mathrm{dS} / \mathrm{cm})$ & 0.43 & & & & \\
\hline
\end{tabular}

CEC: Cation Exchange Capacity, EC: Electricity Conductivity, $\mathrm{NH}_{4}$ : Ammonium, $\mathrm{NO}_{3}$ : Nitrate, $\mathrm{K}$ : Potassium, $\mathrm{Mg}$ : Magnesium, Ca: Calcium, Cu: Cupper, Mn: Manganese, Zn: Zinc, B: Boron, Na: Sodium 
The bacterial strains Alcaligenes $637 \mathrm{Ca}$, Agrobacterium A18, Staphylococcus MFDCa1, Staphylococcus MFDCa2, Bacillus M3, and Pantoea FF1 were provided by Prof. Dr. Fikrettin Şahin and Assoc. Prof. Dr. Mesude Figen Dönmez. The strains 637Ca, A18, MFDCa1, and MFDCa2 were reported to solubilize carbonate, whereas M3 and FF1 solubilized phosphate in in vitro culture condition (İpek et al. 2014; Turan et al. 2004) (Table 2).

A single bacterial colony from a Nutrient Agar (Neogen Corp.) culture was transferred to flasks filled with $500 \mathrm{~mL}$ Nutrient Broth $(13 \mathrm{~g} / \mathrm{L})$ and grown aerobically in an orbital shaker rotating at $95 \mathrm{rpm}$ for one day at $27{ }^{\circ} \mathrm{C}$. The plant's roots were inoculated by dipping them (İpek et al. 2014) in bacterial suspensions at a concentration of $10^{9} \mathrm{CFU} / \mathrm{mL}$ in sterile water, about $30 \mathrm{~min}$ before plantation. The control plant roots were dipped in sterile water. After planting, the bacterial treatments $\left(10^{9}\right.$ $\mathrm{CFU} / \mathrm{mL}$ bacterial suspension and $250 \mathrm{~mL}$ per plant) were repeated on May $30^{\text {th }}$, June $30^{\text {th }}$, and July $30^{\text {th }}$ of all the years between 2012 and 2015, and watered using irrigation water.

\section{NUTRITION OF PEACH SAPLINGS}

All plants were fertilized using modified Hoagland solution $(224 \mathrm{mg} / \mathrm{kg} \mathrm{N}, 62 \mathrm{mg} / \mathrm{kg} \mathrm{P}, 235 \mathrm{mg} / \mathrm{kg} \mathrm{K}, 160$ $\mathrm{mg} / \mathrm{kg} \mathrm{Ca}, 32 \mathrm{mg} / \mathrm{kg} \mathrm{S}, 24 \mathrm{mg} / \mathrm{kg} \mathrm{Mg}, 3 \mathrm{mg} / \mathrm{kg} \mathrm{FeSO}_{4}, 1.77$ $\mathrm{mg} / \mathrm{kg} \mathrm{Cl}, 0.27 \mathrm{mg} / \mathrm{kg} \mathrm{B}, 0.11 \mathrm{mg} / \mathrm{kg} \mathrm{Mn}, 0.13 \mathrm{mg} / \mathrm{kg} \mathrm{Zn}$, $0.03 \mathrm{mg} / \mathrm{kg} \mathrm{Cu}$ and $0.05 \mathrm{mg} / \mathrm{kg} \mathrm{Mo}$ ) simultaneously with the bacterial treatments.

\section{MEASUREMENT OF THE PLANT GROWTH PARAMETERS}

To determine the effect of PGPRs on plant growth, parameters such as leaf area $\left(\mathrm{cm}^{2}\right)$, trunk diameter $(\mathrm{mm})$, shoot length $(\mathrm{cm})$, and chlorophyll content (SPAD unit) were evaluated. The trunk diameter and shoot length were measured using digital calipers (Mitutoyo 500-18130). The leaves were scanned with an indicator (a ruler) using a scanner, and the images were processed using the software Adobe Photoshop CS6 Extend to calculate the leaf area as $\mathrm{cm}^{2}$ based on the pixel value. The chlorophyll content was measured using SPAD-502 Plus (Konica Minolta Inc.), which determines the relative amount of chlorophyll present by measuring the absorbance of the leaf in two wavelength regions.

\section{NUTRIENT ANALYSIS OF THE LEAVES}

The peach leaves that were fully developed on mid-shoot were collected. To assess the nutrient composition, the leaf samples were dried in an oven at $68^{\circ} \mathrm{C}$ for two days and then grounded to a powder to pass through a $1 \mathrm{~mm}$ sieve. The Kjeldahl method and a Vapodest 10 Rapid Kjeldahl Distillation Unit were used to determine the total nitrogen content (Bremner 1996). The content of macro- and micro-elements was determined after wet digestion of the dried and ground sub-samples using a nitric acid-hydrogen peroxide $\left(\mathrm{HNO}_{3}-\mathrm{H}_{2} \mathrm{O}_{2}\right)$ mixture $(2: 3$ $\mathrm{v} / \mathrm{v}$ ) with three steps in a microwave oven (Mertens 2005). An Inductive Coupled Plasma Spectrometer (Optima 2100 DV, Perkin-Elmer) was used to determine the content of macro- and micro-elements (Mertens 2005).

\section{EXPERIMENTAL DESIGN}

The study used a complete randomized design with three replicates per treatment and three saplings per replicate (two rootstocks $\times$ seven treatments $\times$ three replicates $\times$ three plants $=126$ peach saplings).

\section{STATISTICAL ANALYSIS}

All the data were subjected to the tests analysis of variance (ANOVA) and Duncan's multiple range test using the statistical software SPSS 23.0 (SAS Inc.). There were no statistical differences between the years. Therefore, data collected over the three years were pooled for analysis.

\section{RESULTS AND DISCUSSION}

High calcareous content in the soil has negatively affected one-third of the world's land. Concentrations of important plant nutrients such as $\mathrm{Fe}, \mathrm{Mn}, \mathrm{Cu}, \mathrm{B}$, and $\mathrm{Zn}$ are usually low in calcareous soil (İpek \& Eşitken 2017). High bicarbonate concentration in the soil leads to a decrease in Fe uptake by plants. Iron is a vital element for plant growth and metabolic activities (Marschner 2011). Although the total Fe content in the soil is generally abundant, its uptake by plants is constantly impaired by certain soil components such as lime. In the Mediterranean countries and Turkey, fruit trees are generally grown in soils with high lime content or high $\mathrm{pH}$ levels (Fernandez-Lopez et al. 1993). Iron affects several metabolic and physiological processes in plants. Electron transfer, chlorophyll synthesis, and photosynthesis are negatively affected by iron-deficiency (Larbi et al. 2006; Rombolà \& Tagliavini 2006). Besides, iron-deficiency not only affects plant growth but also hampers fruit yield and quality (Mengel 1994). 
TABLE 2. Effects of bacterial strains on the soil or plants

\begin{tabular}{|c|c|c|c|c|c|c|c|}
\hline Strain & $\begin{array}{c}\text { Auxin } \\
\text { Production }\end{array}$ & $\begin{array}{l}\text { Cytokine } \\
\text { Production }\end{array}$ & $\begin{array}{c}\text { ACC- } \\
\text { Deaminase }\end{array}$ & $\begin{array}{c}\mathrm{P} \\
\text { solubilizing }\end{array}$ & $\begin{array}{c}\mathrm{N}_{2} \\
\text { Fixing }\end{array}$ & $\begin{array}{c}\mathrm{Ca}\left(\mathrm{HCO}_{3}\right)_{2} \\
\text { solubilization }\end{array}$ & References \\
\hline $637 \mathrm{Ca}$ & ND & ND & - & ND & - & + & $\begin{array}{l}\text { Ipek et al. } \\
\text { (2014) }\end{array}$ \\
\hline A18 & + & + & - & - & - & + & $\begin{array}{l}\text { Esitken et al. } \\
\text { (2003) }\end{array}$ \\
\hline FF1 & ND & ND & + & + & W & - & $\begin{array}{l}\text { Ipek et al. } \\
\text { (2014) }\end{array}$ \\
\hline M3 & + & + & ND & + & + & W & $\begin{array}{l}\text { Turan et al. } \\
\text { (2004) }\end{array}$ \\
\hline MFDCa1 & ND & ND & - & - & - & + & $\begin{array}{l}\text { Ipek et al. } \\
\text { (2014) }\end{array}$ \\
\hline MFDCa2 & ND & ND & - & - & - & + & $\begin{array}{l}\text { Ipek et al. } \\
\text { (2014) }\end{array}$ \\
\hline
\end{tabular}

ND: Not determined, W: Weak, +: Produce, -: Not produce

Microbes play a significant role in nutrient uptake. Some microelements $(\mathrm{Fe}, \mathrm{Mn}, \mathrm{Cu}, \mathrm{B}$, and $\mathrm{Zn})$ are solubilized by PGPR, increasing their availability for plant uptake (Glick 1995). There are numerous studies on the testing of PGPR strains on different plant species, including apple, cherry, mint, radish, raspberry, strawberry, sour cherry and tomatoes in different soil conditions (Arikan \& Pirlak 2016; Esitken et al. 2006; Ipek et al. 2014; Karakurt et al. 2011; Karlidag et al. 2007; Kaymak et al. 2009, 2008; Orhan et al. 2006; Turan et al. 2004).

This is the first study to demonstrate that the inoculation of PGPR in the roots of different rootstocks for peach improves plant growth and mineral contents under high lime conditions. The PGPR strains Agrobacterium A18, Alcaligenes 637Ca, Bacillus M3, Staphylococcus MFDCa-1, Staphylococcus MFDCa-2, and Pantoea FF1 significantly increased plant growth and plant nutrient content of the peach cultivar 'Elegant Lady' grafted onto Nemaguard and GF677 rootstocks.

\section{THE EFFECTS OF PGPR TREATMENT ON PLANT GROWTH}

The results of plant growth parameters and nutrient content in the present study are presented in Tables 2 , 3 , and 4. Figure 1(A) to 1(D) illustrates the effects of PGPR strains on plant growth. Compared to the control, the GF677 rootstock showed improved performance than Nemaguard rootstock in terms of the plant morphological parameters. Besides, the leaf area was observed to be larger in GF677 treated with FF1, MFDCa1, $637 \mathrm{Ca}$, and in Nemaguard treated with FF1, M3 and MFDCa2 bacteria than control saplings in both rootstocks.

The positive contribution of bacterial strains on growth parameters may be attributed to their ability to fix nitrogen $\left(\mathrm{N}_{2}\right)$, solubilize phosphate and $\mathrm{Ca}\left(\mathrm{HCO}_{3}\right)_{2}$. produce cytokinin and indole acetic acid (IAA), and exhibit ACC deaminase activity (Table 1) (Esitken et al. 2003; İpek et al. 2014; Turan et al. 2004). Bacteria growing in calcareous soil may have a positive effect on 
the growth and development of plants by fixing nitrogen and increasing the uptake of elements such as $\mathrm{P}, \mathrm{Mg}, \mathrm{K}$, and Fe from the soil. This fact is supported by the presence of these elements at higher concentrations in plants treated with bacteria than untreated plants. Nitrogen affects several physiological events, such as cell division, chlorophyll synthesis, and photosynthesis (Marschner 1995). Also, root growth occurs better with an adequate supply of nitrogen. Thus, plants treated with bacteria with better nitrogen nutrition grew better than control plants.

Phosphorus is another essential component of energy metabolism in plants. It also promotes root growth. Plants treated with bacteria that have a better supply of nitrogen and phosphorus show improved ability to absorb minerals and water from the soil. Moreover, bacteriatreated plants show excessive root growth and develop more sites for cytokine synthesis. Thus, the cytokine required for shoot growth may be provided in higher concentrations by the roots.

Magnesium is an important component of chlorophyll. Bacteria-treated plants that absorb more $\mathrm{Mg}$ show increased photosynthetic activity by producing more chlorophyll. Similarly, Fe is required for chlorophyll synthesis. Since sufficient Fe cannot be taken from calcareous soil, chlorosis occurs, and consequently, photosynthetic activity decreases significantly (Marschner 1995; Tagliavini \& Rombolà 2001). Increased uptake of Fe from the soil with the application of bacteria may increase the photosynthetic activity by facilitating more chlorophyll synthesis. Increased photosynthetic activity may lead to higher growth of shoots and roots (Arikan et al. 2020). Better root growth may increase plant growth by promoting the uptake of water and minerals from the soil and facilitating cytokine synthesis in the root.

These bacterial strains can survive in calcareous soil conditions and may reduce the unfavorable effects of high lime content. Although the levels of phytohormones were not analyzed in this present study, the results indicated that levels of cytokinin in plants may have been directly or indirectly affected by bacterial inoculation. The direct effect of bacterial strains may be explained by the increased production of cytokinin (Tsukanova et al. 2017). In this context, the largest leaf areas measured in plants on Nemaguard rootstocks inoculated with MFDCa2, FF1 and M3 were $29.2 \mathrm{~cm}^{2}, 28.8 \mathrm{~cm}^{2}$, and $28.1 \mathrm{~cm}^{2}$, respectively, whereas those in plants on GF677 inoculated with MFDCa1, FF1 and $637 \mathrm{Ca}$ were $34.7 \mathrm{~cm}^{2}$, $32.6 \mathrm{~cm}^{2}$, and $31.5 \mathrm{~cm}^{2}$, respectively (Figure $1(\mathrm{~A})$ ).

The highest trunk diameters in the case of Nemaguard rootstocks were obtained after inoculation with MFDCa1 (36.6 mm), A18 (35.7 mm), 637Ca (34.2 $\mathrm{mm}), \mathrm{M} 3$ (32.6 mm), and FF1 (32.5 mm), whereas in the GF677 rootstocks, inoculation with M3 (43.9 $\mathrm{mm}$ ) and FF1 $(41.3 \mathrm{~mm})$ resulted in the highest trunk diameters (Figure 1(B)). The longest shoots were obtained by inoculation with FF1 $(32.8 \mathrm{~cm}), \mathrm{M} 3(32.7 \mathrm{~cm})$, and $637 \mathrm{Ca}$ $(31.0 \mathrm{~cm})$ onto Nemaguard, whereas A18 $(43.6 \mathrm{~cm})$ and MFDCa2 $(41.9 \mathrm{~cm})$ treatment resulted in the longest shoots on GF677 (Figure 1(C)).

The highest chlorophyll content was observed by inoculation with M3 (50.4 SPAD units) onto Nemaguard, while M3 (45.0 SPAD units), MFDCa1 (44.2 SPAD units) and MFDCa2 (42.9 SPAD units) treatments on GF677 rootstocks resulted in the highest chlorophyll content (Figure 1(D)). The chlorophyll content in the leaves is closely associated with the nutritional status of the plant. For any plant species, a higher SPAD value indicates a healthier plant (Uddling et al. 2007). In this study, the chlorophyll content reached the highest value by the treatment of the rootstocks with M3, MFDCA1, and MFDCa2. This positive influence of bacterial strains on chlorophyll content can be attributed to their ability to fix $\mathrm{N}_{2}(\mathrm{M} 3)$ and solubilize $\mathrm{Ca}\left(\mathrm{HCO}_{3}\right)_{2}$ (MFDCA1 and MFDCa2).

\section{THE EFFECT OF PGPR ON MINERAL CONTENT OF THE LEAF}

The nutrient content of leaves was significantly increased by treatment with the bacterial strains, in comparison to the control group (Tables 3 and 4). The saplings grafted onto the GF677 rootstock showed higher nutrient content compared to those grafted onto Nemaguard rootstocks. Bacterial treatments also significantly affected the macronutrient content of the saplings grafted onto rootstocks. The $\mathrm{N}$ content of leaves increased significantly with all bacterial applications in the GF677 rootstock. In Nemaguard, excluding the A18 bacteria application, the rest of the bacterial treatments increased $\mathrm{N}$ content in leaves. The content of $\mathrm{P}$ increased in plants on Nemaguard rootstock with all bacterial applications, whereas in the case of GF677 rootstock, it increased significantly in all bacterial applications except MFDCa1 and MFDCa2. 


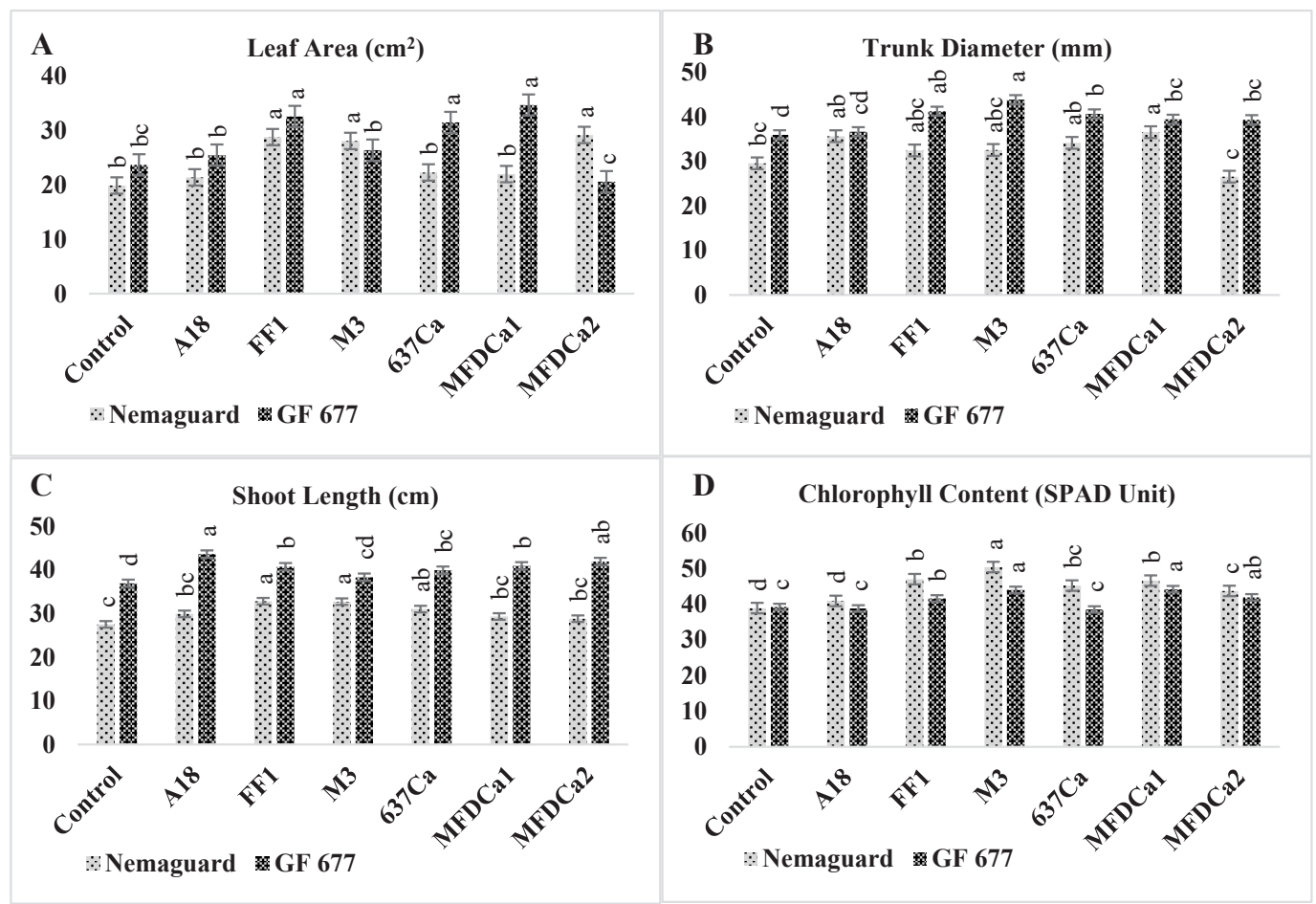

FIGURE 1. Morphological parameters of the peach cultivar 'Elegant Lady' grafted onto Nemaguard and GF677 (A: Leaf area, B: Trunk diameter, C: Shoot length, D: Chlorophyll content)

The $\mathrm{K}$ content was significantly increased in plants on the Nemaguard rootstock with FF1, M3, and MFDCa2, whereas in the case of GF677, only the bacterial treatments with MFDCa2 resulted in a non-significant increase in the $\mathrm{K}$ content. The level of $\mathrm{Ca}$ increased significantly in plants on the Nemaguard and GF677 rootstocks treated with $\mathrm{M} 3$. The $\mathrm{Mg}$ content increased in plants grafted onto Nemaguard rootstock treated with only M3 strains, whereas in the case of GF677, it increased in plants treated with FF1, M3, and MFDCa2. The highest $\mathrm{N}$ content was observed in plants on Nemaguard rootstock treated with M3 (3.44\%), FF1 (3.33\%), MFDCa1 (3.33\%), 637Ca (3.32\%) and MFDCa2 (3.29\%), while treatment with M3 (3.60\%), FF1 (3.57\%), MFDCa2 (3.56\%), A18 (3.44\%) and MFDCa1 (3.44\%) resulted in the highest $\mathrm{N}$ content in plants on GF677 (Table 3).
The $\mathrm{P}$ content of leaves reached the highest-level following treatment with M3 $(0.300 \%)$, MFDCa2 $(0.300 \%)$, FF1 $(0.293 \%)$, and MFDCa1 $(0.280 \%)$ onto Nemaguard, whereas only the M3 treatment onto the GF677 rootstock showed the highest P content $(0.320 \%)$. Potassium (K), which is an important macro-element was increased in plants grafted onto Nemaguard rootstocks treated with M3 (2.67\%) and MFDCa2 (2.65\%). On the other hand, all treatments on GF677 resulted in K content ranging from $2.42 \%$ to $2.66 \%$ (Table 3 ). The $\mathrm{Ca}$ content was observed to be higher in M3 (3.02\%) treatment than other treatments onto Nemaguard, whereas M3 (3.37\%), MFDCa2 (3.31\%) and 637Ca (3.28\%) treatments resulted in higher Ca levels in plants grafted onto GF677. Most of the bacterial treatments showed a significant increase in $\mathrm{Mg}$ content in leaves of saplings 
grafted onto both rootstocks. This result was similar to that observed for $\mathrm{N}$ content (Table 3).

The bacterial treatments resulted in a significant increase in the micronutrient content of saplings grafted onto both Nemaguard and GF677, compared to the control. In saplings grafted onto Nemaguard rootstock, the bacterial treatments successfully increased the Fe content from $35.18 \%$ to $61.18 \%$, and the highest Fe content was observed in treatments with $637 \mathrm{Ca}(133.49$ $\mathrm{mg} / \mathrm{kg}$ ) and M3 (127.64 mg/kg). In saplings grafted onto the GF677 rootstock, the Fe content was observed to be increased between $16.56 \%$ and $49.14 \%$, and the highest Fe content was observed in treatments with MFDCa1 $(131.51 \mathrm{mg} / \mathrm{kg}), 637 \mathrm{Ca}(131.21 \mathrm{mg} / \mathrm{kg}), \mathrm{FF} 1(127.72 \mathrm{mg} /$ $\mathrm{kg}$ ), and M3 (127.68 mg/kg). The MFDCa2 and control groups showed the lowest $\mathrm{Zn}$ content, whereas all the other bacterial treatments significantly increased the $\mathrm{Zn}$ content in plants grafted onto both rootstocks (Table 4).

Regarding $\mathrm{Cu}$ content, treatment of Nemaguard rootstocks with MFDCa1 (20.91 mg/kg), FF1 (20.75 mg/ $\mathrm{kg})$, and $\mathrm{M} 3(19.10 \mathrm{mg} / \mathrm{kg})$ resulted in higher $\mathrm{Cu}$ content, while treatment of the GF677 rootstock with MFDCa1 $(26.05 \mathrm{mg} / \mathrm{kg})$ and FF1 $(25.62 \mathrm{mg} / \mathrm{kg})$ resulted in higher $\mathrm{Cu}$ content than other treatments. The $\mathrm{B}$ content of the saplings was observed to be higher in $637 \mathrm{Ca}(18.68$ $\mathrm{mg} / \mathrm{kg})$, MFDCa1 (17.67 mg/kg), and FF1 (17.46 mg/kg) treatment onto Nemaguard, while only the $637 \mathrm{Ca}(22.98$ $\mathrm{mg} / \mathrm{kg}$ ) treatment on GF677 resulted in the highest B content. Treatment of Nemaguard with FF1 resulted in the highest $\mathrm{Mn}$ content $(93.47 \mathrm{mg} / \mathrm{kg})$, whereas treatments of GF677 with FF1 $(94.86 \mathrm{mg} / \mathrm{kg})$ and MFDCa1 $(89.72 \mathrm{mg} / \mathrm{kg})$ resulted in higher Mn content.

The six bacterial strains tested in this study produced more carbohydrates and cytokinin, resulting in increased leaf area and improved plant growth and development. Furthermore, these bacterial strains also promote the uptake of $\mathrm{Ca}$ (Table 3). During cell division, Ca could be a secondary messenger for cytokines (Saunders 1992). The observed improvement of plant growth and development by PGPR strains could be explained by the differences in the production of IAA and cytokinin, the capacity to solubilize $\mathrm{Ca}\left(\mathrm{HCO}_{3}\right)_{2}$, and/ or colonization capability of PGPR strains. The mineral content may provide important information on the uptake of nutrient elements by the inoculated bacteria.
Generally, it has been reported that plants inoculated with PGPR show higher macro- and microelement content compared to the control plants. Enhancement of mineral uptake by plants results in improved plant growth and increased levels of minerals in the leaves of plants. This is the first study to investigate the increase in the macro- and microelement contents in peach leaves by treatment with the bacterial strains M3, FF1, MFDCa-1, 637Ca, MFDCa-2, and A18 in plants grown under high calcareous soil conditions. These bacterial strains have been previously tested on raspberry, apricot, strawberry, and sweet cherry. The researchers have reported similar findings, confirming our data (Esitken et al. 2010, 2006, 2003; Ipek et al. 2014; Orhan et al. 2006).

The use of the M3 strain in apricot (Esitken et al. 2003), raspberry (Orhan et al. 2006), strawberry (Esitken et al. 2010; Ipek et al. 2014) and sweet cherry (Esitken et al. 2006) has been reported to promote the uptake of macro- and micronutrients. Although M3 strain treatments have been reported to only increase the $\mathrm{N}$ and P content (Çakmakçı et al. 2014, 2007, 2001; Elkoca et al. 2007; Esitken et al. 2010; Ipek et al. 2014), in our study, this strain increased the content of $\mathrm{N}, \mathrm{P}, \mathrm{K}, \mathrm{Ca}$, and $\mathrm{Fe}$ in both rootstocks. It was reported that an increase in the $\mathrm{N}$ content in plants is the result of greater nutrient uptake from the soil (Marschner 1995). The results of this study corroborated with the findings of previous studies on plants inoculated with bacterial strains.

The M3 strain has been reported to decrease soil $\mathrm{pH}$ from 6.7 to 6.0 (Orhan et al. 2006). The uptake of plant nutrient elements such as $\mathrm{P}, \mathrm{Ca}, \mathrm{Fe}$, and $\mathrm{Mn}$ is stimulated by a decrease in soil pH (Cakmakci et al. 2007; Orhan et al. 2006). Because of the solubilization of $\mathrm{Ca}\left(\mathrm{HCO}_{3}\right)_{2}$, bacterial inoculation prevents the formation of the Ca-P complex, thus improving their uptake by plants inoculated with bacteria. It has also been reported that the M3 strain increased root length in some plant species, such as pistachio, barley and chickpea (Cakmakci et al. 2007; Elkoca et al. 2007; Orhan et al. 2006). It is known that the effective use of plant nutrient elements depends on the number of roots in contact with the plant nutrients, as well as the capacity of the root to absorb the contacted plant nutrients (Adepetu \& Akapa 1977). The plants inoculated with bacteria are more capable of uptaking minerals from the soil, resulting in healthy plants and increased content of nutrient elements in the leaves. 
TABLE 3. Effects of bacterial strains on the plant macronutrient content

\begin{tabular}{|c|c|c|c|c|c|c|c|c|c|c|}
\hline \multirow{2}{*}{ Treatments } & \multicolumn{2}{|c|}{ N (\%) } & \multicolumn{2}{|c|}{$\mathrm{P}(\%)$} & \multicolumn{2}{|c|}{$\mathrm{K}(\%)$} & \multicolumn{2}{|c|}{$\mathrm{Ca}(\%)$} & \multicolumn{2}{|c|}{$\operatorname{Mg}(\%)$} \\
\hline & Nemaguard & GF 677 & Nemaguard & GF 677 & Nemaguard & GF 677 & Nemaguard & GF 677 & Nemaguard & GF 677 \\
\hline Control & $3.11 \mathrm{c}$ & $3.23 \mathrm{~d}$ & $0.239 \mathrm{c}$ & $0.284 \mathrm{c}$ & $2.13 \mathrm{e}$ & $2.37 \mathrm{c}$ & $2.88 \mathrm{~b}$ & $3.02 \mathrm{c}$ & $0.654 \mathrm{c}$ & $0.678 \mathrm{~b}$ \\
\hline A18 & $3.18 \mathrm{bc}$ & $3.44 \mathrm{bc}$ & $0.272 \mathrm{~b}$ & $0.291 \mathrm{~b}$ & $2.18 \mathrm{de}$ & $2.55 \mathrm{ab}$ & $2.92 \mathrm{~b}$ & $3.09 \mathrm{bc}$ & $0.711 \mathrm{ab}$ & $0.696 \mathrm{~b}$ \\
\hline FF1 & $3.33 \mathrm{ab}$ & $3.57 \mathrm{ab}$ & $0.293 \mathrm{ab}$ & $0.294 \mathrm{~b}$ & $2.43 \mathrm{bc}$ & $2.59 \mathrm{a}$ & $2.86 \mathrm{~b}$ & $3.07 \mathrm{bc}$ & $0.702 \mathrm{ab}$ & $0.817 \mathrm{a}$ \\
\hline M3 & $3.44 \mathrm{a}$ & $3.60 \mathrm{a}$ & $0.300 \mathrm{a}$ & $0.320 \mathrm{a}$ & $2.67 \mathrm{a}$ & $2.57 \mathrm{a}$ & $3.02 \mathrm{a}$ & $3.37 \mathrm{a}$ & $0.719 \mathrm{a}$ & $0.844 \mathrm{a}$ \\
\hline $637 \mathrm{Ca}$ & $3.32 \mathrm{ab}$ & $3.42 \mathrm{c}$ & $0.274 \mathrm{~b}$ & $0.290 \mathrm{~b}$ & $2.39 \mathrm{~cd}$ & $2.60 \mathrm{a}$ & $2.86 \mathrm{~b}$ & $3.28 \mathrm{ab}$ & $0.676 \mathrm{bc}$ & $0.692 \mathrm{~b}$ \\
\hline MFDCa1 & $3.33 \mathrm{ab}$ & $3.44 \mathrm{bc}$ & $0.280 \mathrm{ab}$ & $0.285 \mathrm{c}$ & $2.15 \mathrm{e}$ & $2.66 \mathrm{a}$ & $2.89 \mathrm{~b}$ & $3.07 \mathrm{bc}$ & $0.701 \mathrm{ab}$ & $0.701 \mathrm{~b}$ \\
\hline MFDCa2 & $3.29 \mathrm{ab}$ & $3.56 \mathrm{ab}$ & $0.300 \mathrm{a}$ & $0.285 \mathrm{c}$ & $2.65 \mathrm{ab}$ & $2.42 \mathrm{bc}$ & $2.91 \mathrm{~b}$ & $3.31 \mathrm{ab}$ & $0.692 \mathrm{ab}$ & $0.786 \mathrm{a}$ \\
\hline Mean & 3.28 & 3.46 & 0.279 & 0.292 & 2.37 & 2.53 & 2.90 & 3.17 & 0.693 & 0.744 \\
\hline
\end{tabular}

TABLE 4. Effects of bacterial strains on plant micronutrient content

\begin{tabular}{|c|c|c|c|c|c|c|c|c|c|c|}
\hline \multirow{2}{*}{ Treatments } & \multicolumn{2}{|c|}{$\mathrm{Fe}(\mathrm{mg} / \mathrm{kg})$} & \multicolumn{2}{|c|}{$\mathrm{Zn}(\mathrm{mg} / \mathrm{kg})$} & \multicolumn{2}{|c|}{$\mathrm{Cu}(\mathrm{mg} / \mathrm{kg})$} & \multicolumn{2}{|c|}{$\mathrm{B}(\mathrm{mg} / \mathrm{kg})$} & \multicolumn{2}{|c|}{$\mathrm{Mn}(\mathrm{mg} / \mathrm{kg})$} \\
\hline & Nemaguard & GF 677 & Nemaguard & GF 677 & Nemaguard & GF 677 & Nemaguard & GF 677 & Nemaguard & GF 677 \\
\hline Control & $82.82 \mathrm{~d}$ & $93.84 \mathrm{c}$ & $21.02 \mathrm{~b}$ & $21.92 \mathrm{c}$ & $15.71 \mathrm{c}$ & $21.36 \mathrm{de}$ & $13.37 \mathrm{c}$ & $17.30 \mathrm{c}$ & $74.12 \mathrm{e}$ & $72.02 \mathrm{e}$ \\
\hline A18 & $112.15 \mathrm{c}$ & $115.84 \mathrm{~b}$ & $25.31 \mathrm{a}$ & $26.43 \mathrm{ab}$ & $18.32 \mathrm{~b}$ & $23.70 \mathrm{bc}$ & $14.29 \mathrm{bc}$ & $16.68 \mathrm{c}$ & $76.39 \mathrm{de}$ & 74.94 de \\
\hline FF1 & $119.01 \mathrm{~b}$ & $127.72 \mathrm{a}$ & $27.80 \mathrm{a}$ & $26.57 \mathrm{a}$ & $20.75 \mathrm{a}$ & $25.62 \mathrm{ab}$ & $17.46 \mathrm{a}$ & $20.35 \mathrm{~b}$ & $93.47 \mathrm{a}$ & $94.86 \mathrm{a}$ \\
\hline M3 & $127.64 \mathrm{a}$ & $127.68 \mathrm{a}$ & $27.58 \mathrm{a}$ & $27.21 \mathrm{a}$ & $19.10 \mathrm{ab}$ & $20.98 \mathrm{de}$ & $15.75 \mathrm{~b}$ & $18.45 \mathrm{c}$ & $84.75 \mathrm{~b}$ & $87.49 \mathrm{~b}$ \\
\hline $637 \mathrm{Ca}$ & $133.49 \mathrm{a}$ & $131.21 \mathrm{a}$ & $25.61 \mathrm{a}$ & $28.31 \mathrm{a}$ & $17.64 \mathrm{bc}$ & $21.89 \mathrm{~cd}$ & $18.68 \mathrm{a}$ & $22.98 \mathrm{a}$ & 80.99 bc & $80.91 \mathrm{c}$ \\
\hline MFDCa1 & $120.94 \mathrm{~b}$ & $131.51 \mathrm{a}$ & 26.33 a & $25.71 \mathrm{ab}$ & 20.91 a & $26.05 \mathrm{a}$ & $17.67 \mathrm{a}$ & $17.55 \mathrm{c}$ & $80.99 \mathrm{bc}$ & $89.72 \mathrm{ab}$ \\
\hline $\mathrm{MFDCa} 2$ & $111.96 \mathrm{c}$ & $109.38 \mathrm{~b}$ & $22.50 \mathrm{~b}$ & $23.68 \mathrm{bc}$ & $15.84 \mathrm{c}$ & $19.30 \mathrm{e}$ & $14.18 \mathrm{bc}$ & $17.78 \mathrm{c}$ & $79.34 \mathrm{~cd}$ & $78.35 \mathrm{~cd}$ \\
\hline Mean & 115.43 & 119.59 & 25.16 & 25.69 & 18.32 & 22.70 & 18.32 & 18.72 & 81.43 & 82.61 \\
\hline
\end{tabular}

\section{CONCLUSION}

High calcareous content in soil is a major problem in the Mediterranean countries and causes nutrient deficiency for plants. Several horticultural species, especially fruits, are highly vulnerable to high calcareous content. Farmers try to cope with this problem by using tolerant rootstock and commercial chelated fertilizers. However, there is no common tolerant rootstock for all fruit species. To overcome the high calcareous content, commercial chelated fertilizers are used to compensate for the lack 
of micronutrients. The intensive use of these chelated fertilizers causes environmental problems (pollution, salinity, and useless groundwater) and higher production cost for fruit growers. For sustainable agricultural production, good agricultural practices and biological applications represent a potential solution. The PGPR could appear to resolve the issues of micronutrient availability and deficiency by solubilizing calcium bicarbonate, producing auxins, cytokines, gibberellins, organic acid and siderophore, and synthesizing ACCdeaminase. This research presents the effectiveness of bacterial strains and rootstocks on plant growth and mineral uptake. For further research, the availability of $\mathrm{Fe}, \mathrm{Zn}, \mathrm{Mn}, \mathrm{Cu}$, and $\mathrm{B}$ under high calcareous soil conditions should be investigated.

\section{ACKNOWLEDGEMENTS}

This study was supported by TUBITAK (TOVAG 1110704), the Scientific and Technological Research Council of Turkey.

\section{REFERENCES}

Adepetu, J. \& Akapa, L. 1977. Root growth and nutrient uptake characteristics of some cowpea varieties. Agronomy Journal 69: 940-943.

Arikan, Ş. \& Pirlak, L. 2016. Effects of plant growth promoting rhizobacteria (PGPR) on growth, yield and fruit quality of sour cherry (Prunus cerasus L.). Erwerbs-obstbau 58(4): 221-226.

Arikan, Ş., İpek, M., Eşitken, A., Pirlak, L., Dönmez, M.F. \& Turan, M. 2020. Plant growth promoting rhizobacteria mitigate deleterious combined effects of salinity and lime in soil in strawberry plants. Journal of Plant Nutrition 40(13): 2028-2039.

Bremner, J. 1996. Nitrogen-total methods of soil analysis: Part 3. Chemical Methods 5: 1085-1121.

Cakmakci, R., Turan, M., Gulluce, M. \& Sahin, F. 2014. Rhizobacteria for reduced fertilizer inputs in wheat (Triticum aestivum spp. vulgare) and barley (Hordeum vulgare) on Aridisols in Turkey. International Journal of Plant Production 8(2): 163-182.

Cakmakci, R., Dönmez, M.F. \& Erdoğan, Ü. 2007. The effect of plant growth promoting rhizobacteria on barley seedling growth, nutrient uptake, some soil properties, and bacterial counts. Turkish Journal of Agriculture and Forestry 31: 189-199.

Çakmakçı, R., Kantar, F. \& Sahin, F. 2001. Effect of $\mathrm{N}_{2}$-fixing bacterial inoculations on yield of sugar beet and barley. Journal of Plant Nutrition and Soil Science 164: 527-531.

Egamberdiyeva, D. 2005. Plant-growth-promoting rhizobacteria isolated from a Calcisol in a semi-arid region of Uzbekistan: Biochemical characterization and effectiveness. Journal of Plant Nutrition and Soil Science 168: 94-99.

Elkoca, E., Kantar, F. \& Sahin, F. 2007. Influence of nitrogen fixing and phosphorus solubilizing bacteria on the nodulation, plant growth, and yield of chickpea. Journal of Plant Nutrition 31: 157-171.

Esitken, A., Yildiz, H.E., Ercisli, S., Donmez, M.F., Turan, M. \& Gunes, A. 2010. Effects of plant growth promoting bacteria (PGPB) on yield, growth and nutrient contents of organically grown strawberry. Scientia Horticulturae 124: 62-66.

Esitken, A., Karlidag, H., Ercisli, S., Turan, M. \& Sahin, F. 2003. The effect of spraying a growth promoting bacterium on the yield, growth and nutrient element composition of leaves of apricot (Prunus armeniaca L. cv. Hacihaliloglu). Australian Journal of Agricultural Research 54: 377-380.

Esitken, A., Pirlak, L., Turan, M. \& Sahin, F. 2006. Effects of floral and foliar application of plant growth promoting rhizobacteria (PGPR) on yield, growth and nutrition of sweet cherry. Scientia Horticulturae 110: 324-327.

Eşitken, A., Karlidăg, H., Ercişli, S. \& Şahin, F. 2002. Effects of foliar application of Bacillus subtilis Osu-142 on the yield, growth and control of shot-hole disease (Coryneum blight). Gartenbauwissenschaft 67: 139.

Fernandez-Lopez, J., Lopez-Roca, J. \& Almela, L. 1993. Mineral composition of iron chlorotic Citrus limon L. leaves. Journal of Plant Nutrition 16: 1395-1407.

García de Salamone, I.E., Hynes, R.K. \& Nelson, L.M. 2001. Cytokinin production by plant growth promoting rhizobacteria and selected mutants. Canadian Journal of Microbiology 47: 404-411.

Glick, B.R. 1995. The enhancement of plant growth by freeliving bacteria. Canadian Journal of Microbiology 41: 109-117.

İpek, M. \& Eşitken, A. 2017. The actions of PGPR on micronutrient availability in soil and plant under calcareous soil conditions: An evaluation over Fe nutrition. In Plant-Microbe Interactions in Agro-Ecological Perspectives, edited by Singh D., Singh H., Prabha R. Singapore: Springer. https://doi.org/10.1007/978-981-10-6593-4_4.

İpek, M., Pirlak, L., Esitken, A., Figen, D.M., Turan, M. \& Sahin, F. 2014. Plant growth-promoting rhizobacteria (PGPR) increase yield, growth and nutrition of strawberry under high-calcareous soil conditions. Journal of Plant Nutrition 37(7): 990-1001.

Karakurt, H. \& Aslantas, R. 2010. Effects of some plant growth promoting rhizobacteria (PGPR) strains on plant growth and leaf nutrient content of apple. Journal of Fruit and Ornamental Plant Research 18: 101-110.

Karakurt, H., Kotan, R., Dadaşoğlu, F., Aslantaş, R. \& Şahin, F. 2011. Effects of plant growth promoting rhizobacteria on fruit set, pomological and chemical characteristics, color values, and vegetative growth of sour cherry (Prunus 
cerasus cv. Kütahya). Turkish Journal of Biology 35: 283291.

Karlidag, H., Esitken, A., Turan, M. \& Sahin, F. 2007. Effects of root inoculation of plant growth promoting rhizobacteria (PGPR) on yield, growth and nutrient element contents of leaves of apple. Scientia Horticulturae 114: 16-20.

Kaymak, H.Ç., Güvenç, İ., Yarali, F. \& Dönmez, M.F. 2009. The effects of bio-priming with PGPR on germination of radish (Raphanus sativus L.) seeds under saline conditions. Turkish Journal of Agriculture and Forestry 33: 173-179.

Kaymak, H., Yarali, F., Guvenc, I. \& Donmez, M.F. 2008. The effect of inoculation with plant growth rhizobacteria (PGPR) on root formation of mint (Mentha piperita L.) cuttings. African Journal of Biotechnology 7(24): 44794483.

Larbi, A., Abadía, A., Abadía, J. \& Morales, F. 2006. Down co-regulation of light absorption, photochemistry, and carboxylation in Fe-deficient plants growing in different environments. Photosynthesis Research 89: 113-126.

Loeppert, R. 1986. Reactions of iron and carbonates in calcareous soils. Journal of Plant Nutrition 9: 214.

Marschner, P. 2011. Marschner's Mineral Nutrition of Higher Plants. 3rd ed. Amsterdam, Netherlands: Elsevier/Academic Press. p. 684.

Marschner, P. 1995. Mineral Nutrition of Higher Plants. 2nd ed. London: Academic Press.

Mengel, K. 1994. Iron availability in plant tissues-iron chlorosis on calcareous soils. Plant and Soil 165: 275-283.

Mertens, D.R. 2005. AOAC official method 975.03. Metal in plants and pet foods. In Official Methods of Analysis. 18th ed., edited by Horwitz, W. \& Latimer, G.W. Gaithersburg, MD.: AOAC-International. pp. 3-4.

Orhan, E., Esitken, A., Ercisli, S., Turan, M. \& Sahin, F. 2006. Effects of plant growth promoting rhizobacteria (PGPR) on yield, growth and nutrient contents in organically growing raspberry. Scientia Horticulturae 111: 38-43.

Rombolà, A.D. \& Tagliavini, M. 2006. Iron Nutrition of Fruit Tree Crops, Iron Nutrition in Plants and Rhizospheric Microorganisms. The Netherlands: Springer. pp. 61-83.

Saunders, M.J. 1992. Cytokinin signal transduction throught $\mathrm{Ca} 2+$ in mosses. In Progress in Plant Growth Regulation, edited by Karssen, C.M., Van Loon, L.C. \& Vreugdenhil, D. Dordrecht, the Netherlands: Kluwer Academic. pp. 65-72.

Sorrenti, G., Toselli, M. \& Marangoni, B. 2012. Use of compost to manage Fe nutrition of pear trees grown in calcareous soil. Scientia Horticulturae 136: 87-94.
Tagliavini, M. \& Rombolà, A.D. 2001. Iron deficiency and chlorosis in orchard and vineyard ecosystems. European Journal of Agronomy 15: 71-92.

Turan, M., Ataoglu, N. \& Sezen, Y. 2004. Effects of phosphorus solubilizing bacteria (Bacillus megaterium) on yield and phosphorus contents of tomato plant (Lycopersicon esculentum L.) III. In Proceedings of Third National Fertilizer Congress, Farming-Industry-Environment. pp: 939-945.

Tsukanova, K.A., Meyer, J.J.M. \& Bibikova, T.N. 2017. Effect of plant growth-promoting Rhizobacteria on plant hormone homeostasis. South African Journal of Botany 113: 91-102.

Uddling, J., Gelang-Alfredsson, J., Piikki, K. \& Pleije, H. 2007. Evaluating the relationship between leaf chlorophyll concentration and SPAD-502 chlorophyll meter readings. Photosynthesis Research 91: 37-46.

Zhang, H., Sun, Y., Xie, X., Kim, M.S., Dowd, S.E. \& Paré, P.W. 2009. A soil bacterium regulates plant acquisition of iron via deficiency-inducible mechanisms. The Plant Journal 58: 568-577.

Muzaffer İpek*, Şeyma Arıkan, Ahmet Eşitken \& Lütfi Pırlak Department of Horticulture

Faculty of Agriculture

University of Selçuk

42075 Konya

Turkey

Mesude Figen Dönmez

Department of Plant Protection

Faculty of Agriculture

University of Iğdır

76000 Iğdır

Turkey

Metin Turan

Department of Genetics and Bioengineering Plant Protection Faculty of Engineering

University of Yeditepe

34755 İstanbul

Turkey

*Corresponding author; email: mipek@selcuk.edu.tr

Received: 28 March 2020

Accepted: 2 February 2021 